International Research Journal of Management, IT \& Social Sciences
Available online at https://sloap.org/journals/index.php/irjmis/
Vol. 6 No. 6, November 2019, pages: 270 277
ISSN: 2395-7492
https://doi.org/10.21744/irjmis.v6n6.809

\title{
Job Satisfaction Moderate in Self-Leadership on Job Performance
}

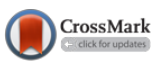

\author{
I Nyoman Adi Setya Darma \\ Ida Bagus Ketut Surya ${ }^{\text {b }}$ \\ I Gusti Made Suwandana ${ }^{c}$
}

Article history:

Received: 27 July 2019

Accepted: 30 September 2019

Published: 30 November 2019

\section{Keywords:}

job performance;

job satisfaction;

MRA test;

relationship;

self-leadership;

\begin{abstract}
The purpose of this study is to analyze the effect of self-leadership on employee job satisfaction and to analyze the role of job satisfaction in moderating the effect of self-leadership on job performance. This study was classified as associative research (relationship) of self-leadership, job performance and job satisfaction at Tjendana Villa Seminyak with 56 respondents. This research analysis technique uses the Moderated Regression Analysis (MRA) Test. The implication of this research can be a company reference to design regulations and policies to improve job satisfaction by taking the Leadership and Job performance that may occur. Based on the results of the research analysis and the results of the discussion, the conclusions of this study are as follows, Self-leadership has a significant positive effect on job performance. Job satisfaction has a significant positive effect on job performance. Job satisfaction strengthens the effect of leadership on job performance.
\end{abstract}

2395-7492@ Copyright 2019. The Author. This is an open-access article under the CC BY-SA license (https://creativecommons.org/licenses/by-sa/4.0/) All rights reserved.

\section{Author correspondence:}

I Nyoman Adi Setya Darma,

Faculty of Economic and Business Udayana University, Bali, Indonesia.

Email address: adisetyadarma@yahoo.com

\section{Introduction}

Job performance means the work that can be achieved by a person or group of people in an organization, in accordance with their respective authorities and responsibilities in an effort to achieve the goals of the organization legally, is not against the law and in accordance with moral ethics (Sedarmayanti, 2014). The performance of an employee plays an important role in an organization because the performance of each employee is a contribution to the achievement of the performance of each organizational function and in turn, the performance of organizational functions contributes to the achievement of organizational performance (Marnis \& Marzolina, 2015). The low performance of employees in an organization can cause an organization to hamper in achieving its goals (Pant \& Yadav, 2016). Performance in

${ }^{a}$ Udayana University, Bali, Indonesia

b Udayana University, Bali, Indonesia

${ }^{\mathrm{c}}$ Udayana University, Bali, Indonesia 
carrying out its functions does not stand alone but is related to job satisfaction and reward levels, affected by skills, abilities and individual traits (Chanana \& Gupta, 2016).

Luthans (2015), performance is basically determined by three things, namely: 1) ability, 2) desire, and 3) environment. Yulyanti (2016), states that every achievement is always followed by the acquisition that has value for the employee concerned, whether in the form of wages, promotions, reprimands, and better jobs. To be able to improve job performance, the management needs to pay attention to the factors that affect it. Factors that affect job performance according to Rahmat et al. (2019), include leadership, self-leadership and job satisfaction.

As for the performance achievement problems encountered at Tjendana Villa Seminyak through interviews with personnel / HRD departments, it was found that there was a lack of employee initiative in completing work quickly, for example in the housekeeping section which often delayed work so that tourists who would check-in had to wait a while, in the food section and beverage often get complaints from tourists for taking too long to order. These things make employees have work results with both quantity and quality of work that are still low, seem minimal in their knowledge and not responsive to instructions related to work methods and existing work situations. Employees show that there are still many problems that indicate low performance in the company.

A leader who uses the leadership style of self-leadership according to Yulyanti (2016), said that self-leadership is a psychological construct that is a person's capacity to improve performance through a repertoire of ongoing cognitive, motivational strategies and self-navigating behavior. According to Luthans (2015), self-leadership is an expansion of strategies focused on behavior, thought patterns, and feelings, which are used to effect on oneself. Self-leadership can also be considered as a form of participation or perhaps more precisely leadership focus on oneself that is able to limit back traditional participation. This type of leadership self-leadership has the ability to assist employees in solving problems, making decisions, and identifying present or future opportunities and challenges (Talsi, 2017).

As for the problems of self-leadership encountered at Tjendana Villa Seminyak such as the lack of attention from leaders, lack of motivation from superiors to employees who are experiencing problems, the lack of leadership roles to help employees in overcoming work problems such as the receptionist who receives complaints from tourists but the leader is not at all willing to help by throwing responsibilities to employees. These things show that there are still many problems that indicate self-leadership from leaders.

The role of leadership in self-leadership is highly expected, given the importance of the role of HR as the hope of every company to have quality human beings who will facilitate them in achieving their goals, so the leadership role is needed to inspire followers to achieve satisfactory performance. An effective leader is done by recognizing the problems faced by employees in providing services through providing motivation, training, education about tourism and language skills so as to be able to improve their intellectual and skills in work (Choi et al., 2015).

Some previous research has proven that job performance can be affected by self-leadership. Marnis \& Marzolina (2015), say that self-leadership has a positive role in improving job performance. Muljono et al. (2015), states that self-leadership is able to affect job performance in carrying out work. This is consistent with the results of research by Faranak et al. (2015), which states that self-leadership variables have a positive effect on job performance effectively.

\section{Literature Review and Hypothesis Development}

Previous research has proven that job performance can be affected by self-leadership. Marnis \& Marzolina (2015), say that self-leadership has a positive role in improving job performance. Talsi (2017), states that self-leadership can affect job performance in carrying out work. This is supported by Faranak et al. (2015), self-leadership has a positive effect on job performance effectively. Esra et al. (2017), stated that leadership has a positive role in improving job performance. O'Dowyer (2014) has shown that leadership has a positive effect on job performance. The same is stated by Woro (2014) self-leadership has a positive effect on job performance. Jessie \& Nesbit (2014), proves that selfleadership has a positive effect on job performance. Sesen et al. (2017), provide the same opinion that self-leadership is the main variable that affects job performance. Putra \& Sintaasih (2018), state that self-leadership has a positive effect on job performance. Intan et al. (2017), proved that self-leadership has a positive effect on job performance effectively. Ria \& Suartana (2014), stated that there is a positive effect of self-leadership on job performance. Amerthadi \& Suana (2016), emphasize in their research that self-leadership has a positive role in improving job performance. Based on this understanding the first hypothesis can be formulated as follows.

H1: Self-leadership has a significant effect on job performance

Some studies prove that job satisfaction is able to moderate or strengthen the effect of self-leadership on job performance. Jessie \& Paul (2014), stated that job satisfaction moderates the effect of self-leadership position job

Darma, I. N. A. S., Surya, I. B. K., \& Suwandana, I. G. M. (2019). Job satisfaction moderate in self-leadership on job performance. International Research Journal of Management, IT and Social Sciences, 6(6), 270-277. https://doi.org/10.21744/irjmis.v6n6.809 
performance. Faranak et al. (2015), in his research proved that employee job satisfaction moderates the effect of selfleadership on job performance. Chang (2017), said that employee job satisfaction has a moderately positive relationship on the effect of self-leadership on job performance. Employee job satisfaction strongly affects the effect of selfleadership on job performance (Sarmawa et al., 2017). Voon et al. (2011), states employee job satisfaction moderates the effect of self-leadership on job performance. Purwanto (2018), proves the same thing job satisfaction moderates the effect of self-leadership on job performance. Choi et al. (2015), stated that employee job satisfaction has a moderately positive relationship on the effect of self-leadership on job performance. Esra et al. (2017), proved in his research that job satisfaction moderates by strengthening the effect of self-leadership on job performance. Paripurna et al. (2017), recorded that employee job satisfaction moderates the effect of self-leadership on job performance. Gede \& Piartini (2018), state that there is a role for job satisfaction in moderating the effect of self-leadership on job performance. Pratiwi \& Erawati (2017), prove that employee job satisfaction has a moderately positive relationship to the effect of self-leadership on job performance. Suprapta et al. (2015), proves that job satisfaction moderates by strengthening the effect of self-leadership on job performance. Based on this understanding the second hypothesis can be formulated as follows.

H2: Job satisfaction moderates the effect of leadership on job performance.

This conceptual model scheme explains that self-leadership and job satisfaction with job performance. For more details, the framework can be seen in Figure 1 as follows.

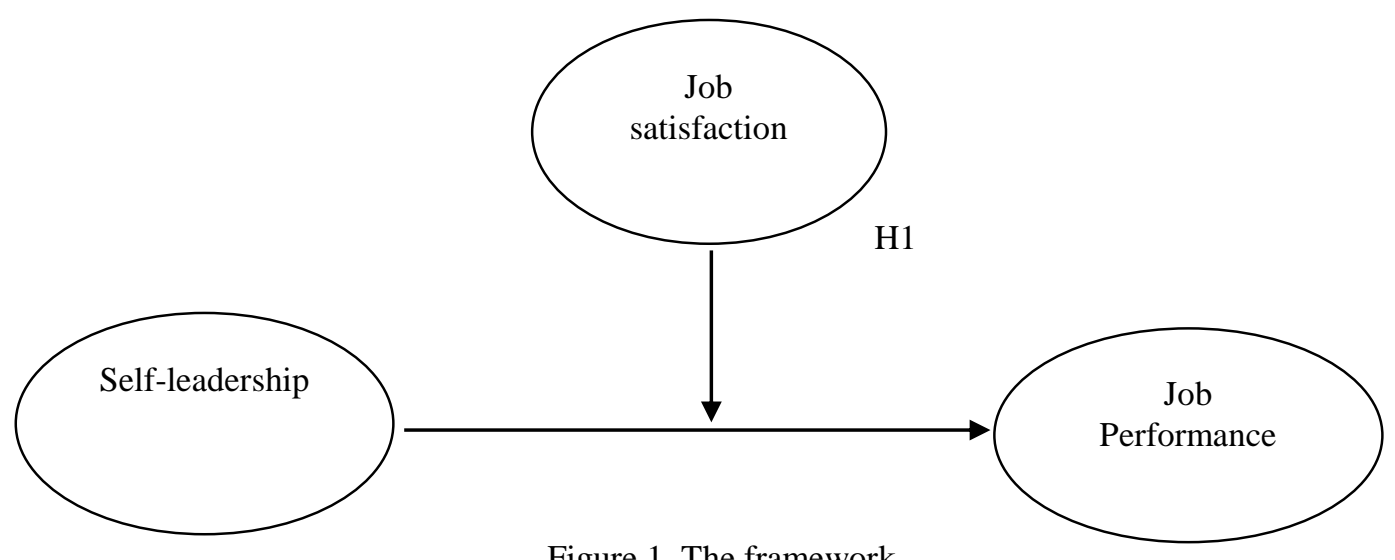

Figure 1. The framework

\section{Materials and Methods}

MRA is an application of multiple linear regression, where the regression equation contains interaction elements (multiplication of two or more independent variables). The regression coefficient analysis test will use the Moderated Regression Analysis (MRA) test. Choosing an MRA in this study explains moderating variables in strengthening or weakening the relationship between the independent and dependent variables.

\section{Results and Discussions}

Moderated Regression Analysis

Table 1

Moderated Regression Analysis

\begin{tabular}{|c|c|c|c|c|c|c|}
\hline \multirow{2}{*}{\multicolumn{2}{|c|}{ Model }} & \multicolumn{2}{|c|}{$\begin{array}{l}\text { Unstandardized } \\
\text { Coefficients }\end{array}$} & \multirow{2}{*}{$\begin{array}{l}\text { Standardized } \\
\text { Coefficients } \\
\text { Beta }\end{array}$} & \multirow[b]{2}{*}{ t } & \multirow[b]{2}{*}{ Sig. } \\
\hline & & $\mathrm{B}$ & Std. Error & & & \\
\hline & (Constant) & 8.391 & 1.866 & & 4.498 & .000 \\
\hline & Self-leadership & .283 & .112 & .322 & 2.532 & .014 \\
\hline
\end{tabular}




\begin{tabular}{|c|c|c|c|c|c|}
\hline Job satisfaction & .392 & .117 & .316 & 3.346 & .002 \\
\hline Self-leadership*job satisfaction & .011 & .005 & .342 & 2.320 & .024 \\
\hline
\end{tabular}

Primary Data, 2019

\section{Hypothesis Testing Results}

To test the hypothesis in this study it can be measured from the coefficient of determination, the F statistical test, and the $\mathrm{t}$ statistical test.

\section{Determination coefficient}

Based on the value of $\mathrm{R}^{2}$ it can be seen what percentage of the dependent variable can be explained by the independent variable, while the rest is an effect or explained by other variables not included in the research model. The adjusted $\mathrm{R}^{2}$ value can go up or down if an independent variable is added to the model.

Table 2

Determination coefficient

\begin{tabular}{lllll}
\hline \multicolumn{2}{l}{ Model Summary } & & \\
\hline Model & $\mathrm{R}$ & $\mathrm{R}$ Square & Adjusted R Square & Std. Error of the Estimate \\
1 & $.855^{\mathrm{a}}$ & .731 & .715 & 1.317 \\
\hline
\end{tabular}

a. Predictors: (Constant), self-leadership*job satisfaction, job satisfaction, self-leadership

b. Dependent Variable: job performance

Primary Data, 2019

Based on table 2 the magnitude of the effect of the independent variable on the dependent variable shown by the total determination value (Adjusted R Square) of 0.715 means that $71.5 \%$ of the variation in self-leadership and job satisfaction as a moderating effect on job performance, while the remaining $28.5 \%$ is explained by other factors not included in the model

F test

The feasibility test of the model is measured by the results of the F test. The criterion used is the significance of $\mathrm{F}>$ Alpha $(\alpha=0.05)$ then an inappropriate regression model is used to predict the effect of the independent variable, but if the significance of $F \leq$ Alpha $(\alpha=0.05)$ then Regression models have met the prerequisites for the feasibility of the regression model.

Table 3

F test

\begin{tabular}{lllllll}
\hline \multicolumn{1}{c}{ ANOVA $^{\mathrm{a}}$} & \multicolumn{1}{c}{} \\
\hline Model & & Sum of Squares & $\mathrm{df}$ & Mean Square & F & Sig. \\
\hline 1 & Regression & 244.664 & 3 & 81.555 & 47.019 & $.000^{\mathrm{b}}$ \\
& Residual & 90.194 & 52 & 1.734 & & \\
& Total & 334.857 & 55 & & & \\
\hline
\end{tabular}

a. Dependent Variable: Job performance

b. Predictors: (Constant), self-leadership*job satisfaction, job satisfaction, self-leadership

Primary Data, 2019

Based on table 3, it can be seen that a significant value of 0,000 is less than $0.05(0,000<0.05)$ so that the model in this study is feasible or the independent variable is able to explain the dependent variable, in other words, the independent variable simultaneously or jointly affects the dependent variable.

Darma, I. N. A. S., Surya, I. B. K., \& Suwandana, I. G. M. (2019). Job satisfaction moderate in self-leadership on job performance. International Research Journal of Management, IT and Social Sciences, 6(6), 270-277. https://doi.org/10.21744/irjmis.v6n6.809 
T test (hypothesis testing)

Statistical test $t$ basically shows how far the effect of one independent variable individually in explaining the dependent variable (Ghozali, 2006). The T-test can be done by looking at the probability of significance of each variable contained in the output of the regression results using SPSS. If the significance value of $t$ is less than 0.05 then H0 is rejected and $\mathrm{H} 1$ means that there is a strong effect between the independent variable and the dependent variable.

Table 4

Hypothesis testing result

\begin{tabular}{|c|c|c|c|c|c|c|}
\hline \multicolumn{7}{|c|}{ Coefficients $^{\mathrm{a}}$} \\
\hline \multirow{2}{*}{\multicolumn{2}{|c|}{ Model }} & & $\begin{array}{l}\text { tandardized } \\
\text { befficients }\end{array}$ & & \multirow[b]{2}{*}{$\mathrm{t}$} & \multirow[b]{2}{*}{ Sig. } \\
\hline & & $\mathrm{B}$ & Std. Error & Beta & & \\
\hline & (Constant) & 8.391 & 1.866 & & 4.498 & .000 \\
\hline & Self-leadership & .283 & .112 & .322 & 2.532 & .014 \\
\hline & Job satisfaction & .392 & .117 & .316 & 3.346 & .002 \\
\hline & Self-leadership*job satisfaction & .011 & .005 & .342 & 2.320 & .024 \\
\hline
\end{tabular}

a. Dependent Variable: Job performance

Source: Data processed, 2019 (Appendix 9)

\section{The Effect of Self-leadership on Job performance}

Based on the analysis results it can be seen that the significant value for the variable of self-leadership is 0.014 less than $0.05(0.014<0.05)$ with a positive coefficient of 0.283 , so H0 is rejected, in other words, self-leadership has a positive effect on job performance. This means that the more self-leadership increases, the job performance will increase, conversely the declining self-leadership will decrease job performance.

Previous research has proven that job performance can be influenced by self-leadership. Marnis \& Marzolina (2015), say that self-leadership has a positive role in improving job performance. Talsi (2017), states that selfleadership can influence job performance in carrying out work. This is supported by Faranak et al. (2015), selfleadership has a positive effect on job performance effectively. Esra et al. (2017), stated that leadership has a positive role in improving job performance. O’Dwyer (2014), has shown that leadership has a positive effect on job performance.

\section{The Effect of Job Satisfaction on Job performance}

Based on the results of the analysis it can be seen that the significant value for the variable job satisfaction is 0.002 less than $0.05(0.002<0.05)$ with a positive coefficient of 0.392 , so H0 is rejected, in other words, job satisfaction has a positive effect on job performance. This means that as job satisfaction increases, job performance will increase, on the contrary decreases job satisfaction, job performance will decrease.

Product quality is defined as anything that satisfies customers or in accordance with requirements or needs (Munisih \& Soliha, 2015). According to the research of Afshar et al. (2011), product quality directly affects customer satisfaction and customer satisfaction directly influences positive behavioral intentions. Raharjo (2013), states that product quality has a positive effect on customer loyalty. In addition, Saputra et al. (2019), states that there is a significant influence between product quality on customer loyalty. Research conducted by Padmantyo \& Fauzi'ah (2014), also states that product quality has a significant effect on customer loyalty.

\section{The Effect of Self-leadership on Job performance with Job Satisfaction as a Moderation Variable}

Based on the analysis results it can be seen that the significant value for the variable of self-leadership with job satisfaction as a moderator is 0.024 less than $0.05(0.024<0.05)$ with a positive coefficient value of 0.011 , so $\mathrm{H} 0$ is rejected, in other words, job satisfaction reinforces the influence of self-leadership towards job performance. This means that increasing self-leadership with job satisfaction as a moderating improve job performance, conversely decreasing self-leadership with job satisfaction as a moderating job performance will decrease. 
Some studies prove that job satisfaction is able to moderate or strengthen the influence of self-leadership on job performance. Jessie \& Paul (2014), stated that job satisfaction moderates the influence of self-leadership position job performance. Faranak et al. (2015), in his research, proved that employee job satisfaction moderates the effect of selfleadership on job performance. Chang (2017), said that employee job satisfaction has a moderately positive relationship on the influence of self-leadership on job performance. Employee job satisfaction strongly influences the influence of self-leadership on job performance (Sarmawa et al., 2017). Voon et al. (2011), states employee job satisfaction moderates the effect of self-leadership on job performance.

\section{Research Implications}

Based on the results of the study will provide implications related to existing knowledge both in general and specifically such as the science of human resources about self-leadership, job satisfaction, and job performance. The results of this study will also strengthen the results of previous studies. Practically it can be a reference for Tjendana Villa Seminyak Manager to design regulations and policies to improve job satisfaction by taking into account the Leadership and Job performance that may occur. In addition, the Manager of Tjendana Villa Seminyak can strive to improve through the results of this study, especially those relating to job performance, because job performance has a positive effect on self-leadership and job satisfaction.

\section{Research Limitations}

In carrying out this research there are certain obstacles that are at the same time a limitation in this study, but it is hoped that this limitation does not become a barrier to other studies to further explore the variables contained in this study and can achieve the desired benefits. These limitations include:

1) The scope of research that chooses the villa as the object of research makes the results of the study less suitable for application to large agencies or companies because the organizational structure is different.

2) The number of variables in this study is limited to 3 variables, namely self-leadership, job satisfaction, and job performance.

The number of samples is limited to Tjendana Villa Seminyak employees. This limitation may not be used as a basis for generalization for other villa employees.

\section{Conclusion}

Self-leadership has a significant positive effect on job performance. This means that the more Self-leadership will improve job performance. Job satisfaction has a significant positive effect on job performance. This means that increasing job satisfaction will improve job performance. Job satisfaction strengthens the influence of leadership on job performance. This means that increasing Self-leadership with job satisfaction as a moderating improve job, conversely decreasing Self-leadership with job satisfaction as a moderating job performance will decrease.

\section{Conflict of interest statement}

The authors declared that they have no competing interests.

\section{Statement of authorship}

The authors have a responsibility for the conception and design of the study. The authors have approved the final article.

\section{Acknowledgments}

The authors would like to thank the reviewer for their consideration of the further process of the present paper. Thanks to the editor of IRJMIS for the valuable support, time as well as advice.

Darma, I. N. A. S., Surya, I. B. K., \& Suwandana, I. G. M. (2019). Job satisfaction moderate in self-leadership on job performance. International Research Journal of Management, IT and Social Sciences, 6(6), 270-277. https://doi.org/10.21744/irjmis.v6n6.809 


\section{References}

Chanana, M., \& Gupta, K. (2016). Quality of work life and its impact on job performance: a study of S.B.I \& HDFC banking professionals. International Research Journal of Management, IT and Social Sciences, 3(5), $16-24$.

Chang, H. (2017). Does leadership matter? Study of leadership style, job performance and job satisfaction. Poslovna ekonomija, 11(2), 1-28.

Diastuti, W. J. Pengaruh Gaya Kepemimpinan Dan Kepuasan Kerja Terhadap Kinerja Karyawan Studi Kasus PT Sarinah (Persero) Jakarta. MIX: Jurnal Ilmiah Manajemen, 4(1).

Esra C. akmak., Ozge Oztekin., \& Engin Karada. (2017). The Effect of Leadership on Job Satisfaction. African Journal of Business Management. 7(1): h: 29-56

Fahruna, Y. (2016). Servant Leadership dan Kepuasan Kerja terhadap Kinerja Karyawan di Lembaga Keuangan Non Bank Pontianak. Jurnal Ekonomi Bisnis dan Kewirausahaan (JEBIK), 5(3), 179-197. http://dx.doi.org/10.26418/jebik.v5i3.19080

Gede, I. K., \& Piartini, P. S. (2018). Pengaruh Kepemimpinan Terhadap Kinerja Karyawan Yang Dimoderasi Oleh Motivasi Kerja Pada Bpr Se-Kecamatan Sukawati Gianyar. E-Jurnal Ekonomi dan Bisnis Universitas Udayana, 7(2018), 1107-1134. https://doi.org/10.24843/EEB.2018.v07.i04.p07

Ghozali, I. (2006). Aplikasi analisis multivariate dengan program SPSS. Badan Penerbit Universitas Diponegoro.

Ho, J., \& Nesbit, P. L. (2014). Self-leadership in a Chinese context: Work outcomes and the moderating role of job autonomy. Group \& Organization Management, 39(4), 389-415. https://doi.org/10.1177\%2F1059601114539389

Intan, I. G. A., \& Supartha, I. W. G., Saroyeni, Putu. (2017). Pengaruh Self efficacy dan Motivasi Berprestasi Terhadap Kinerja Agen Pemasaran Asuransi Equity Life Indonesia Cabang Renon Denpasar. E-Jurnal Ekonomi dan Bisnis Universitas Udayana.

Long, C. S., Alifiah, M. N., Kowang, T. O., \& Ching, C. W. (2015). The relationship between Self-leadership, personality and job satisfaction: A review. Journal of Sustainable Development, $8(1), 16$. http://dx.doi.org/10.5539/jsd.v8n1p16

Luthans, Fred. (2015). Perilaku Organisasi, Edisi kesepuluh, Penerbit Andi Offset.

Marnis \& Marzolina. (2015). Pengaruh Self Leadership terhadap Kinerja Karyawan PT. Perkebunan Nusantara V Riau. Jurnal Administrasi Bisnis. 32(2): h: 1-11

Muljono, Agung., Naely Azhad, M., Herlambang, Toni. (2015). Super Leadership dan Self Leadership: Dampaknya Terhadap Kinerja Pegawai (Kajian Berbasis Riset Pada Lembaga Pendidikan Muhammadiyah Di Kabupaten Jember). Jurnal Manajemen Sumber Daya Manusia. 3(5): h: 300-311

Munisih, S., \& Soliha, E. (2015). Pengaruh Kualitas Produk terhadap Nilai Pelanggan dan Kepuasan Pelanggan dan Dampaknya pada Loyalitas Pelanggan Apotek Dela Semarang. In Prosiding Seminar Nasional \& Call Pappers. Fakultas Ekonomika dan Bisnis Universitas STIKUBANK Semarang.

O'Dwyer, T. (2014). Consequences of self-leadership in an Irish public sector knowledge organisation (Doctoral dissertation, Waterford Institute of Technology).

Padmantyo, S., \& Fauzi'ah, S. (2014). Pengaruh kualitas produk terhadap loyalitas pelanggan dengan kepuasan sebagai variabel moderasi.

Pant, I., \& Yadav, R. K. (2016). Impact of emotional intelligence on the job performance of employee. International Research Journal of Management, IT and Social Sciences, 3(1), 7-14.

Paripurna, I. G. D., Supartha, I. W. G., \& Subudi, M. (2017). Pengaruh kepemimpinan dan kepuasan kerja terhadap turnover intention serta dampaknya terhadap kinerja karyawan pada pt agung automall kuta. E-Jurnal Ekonomi dan Bisnis Universitas Udayana, 2441-2474.

Pratiwi, N. K. L. A., \& Erawati, N. M. A. (2017). Kepuasan Kerja Memoderasi Gaya Kepemimpinan Transformasional dan Budaya Organisasi Berbasis THK Pada Kinerja Organisasi. E-Jurnal Akuntansi, 1848-1872. https://doi.org/10.24843/EJA.2017.v21.i03.p06

Purwanto, E. (2018). Moderation Effects of Power Distance on the Relationship between Job Characteristics, Leadership Empowerment, Employee Participation and Job Satisfaction: A Conceptual Framework. Academy of Strategic Management Journal.

Putra, I. M. A. D., \& Sintaasih, D. K. (2018). The Effect Of Self Leadership And Organizational Commitment To Employee Performance At The Four Points By Sheraton Hotel. E-Jurnal Manajemen, 7(8), 4237-4266. https://doi.org/10.24843/EJMUNUD.2018.v07.i08.p08

Raharjo, H. (2013). On normalizing the relationship matrix in quality function deployment. International Journal of Quality \& Reliability Management, 30(6), 647-661. https://doi.org/10.1108/02656711311325601 
Rahmat, R., Ramly, M., Mallongi, S., \& Kalla, R. (2019). The leadership style effect on the job satisfaction and the performance. Asia Pacific Journal of Management and Education, 2(1). https://doi.org/10.32535/apjme.v2i1.376

Sanjiwani, I. M. A., \& Suana, I. W. (2016). Pengaruh Kepemimpinan Transformasional, Kepuasan Kerja Dan Komitmen Organisasi Terhadap Kinerja Karyawan Bagus Hayden Hotel Kuta, Bali. E-Jurnal Manajemen, 5(2).

Saputra, L. A. A., Surati, -, \& Saufi, A. (2019). Mediation role of job satisfaction towards effect of conflict roles on organizational commitment. International Journal of Social Sciences and Humanities, 3(2), 165-175. https://doi.org/10.29332/ijssh.v3n2.308

Sarmawa, I. W. G., \& Dewi, I. G. A. M. (2017). Influence of self-leadership on employee performance with work culture as mediator: study at tenun ikat industries in klungkung-bali, indonesia.

Satyawati, N. M. R., \& Suartana, I. W. (2014). Pengaruh Gaya Kepemimpinan dan Budaya Organisasi terhadap kepuasan kerja yang berdampak pada kinerja Keuangan. E-Jurnal Akuntansi, 17-32.

Sedarmayanti, H. J. (2014). Manajemen Sumber Daya Manusia, Reformasi Birokrasi, Dan Manajemen Negeri Sipil. Seventh Printing. Bandung: Refika Aditama.

Sesen, H., Tabak, A., \& Arli, O. (2017). Consequences of Self-Leadership: A Study on Primary School Teachers. Educational Sciences: Theory and Practice, 17(3), 945-968.

Shad, F. S., Sharbiyani, A. A. A., \& Abzari, M. (2015). Studying the relation between self-leadership with job satisfaction and performance improvement. Global Journal of Human Resource Management, 3(3), 39-57.

Suprapta, M., Sintaasih, D. K., \& Riana, I. G. (2015). Pengaruh Kepemimpinan Terhadap Kepuasan Kerja Dan Kinerja Karyawan (Studi Pada Wake Bali Art Market Kuta-Bali). E-Jurnal Ekonomi dan Bisnis Universitas Udayana.

Talsi, A. (2017). Employee Perceptions of Follower Self-Leadership in a Large Company.

Voon, M. L., Lo, M. C., Ngui, K. S., \& Ayob, N. B. (2011). The influence of leadership styles on employees' job satisfaction in public sector organizations in Malaysia. International Journal of Business, Management and Social Sciences, 2(1), 24-32.

Darma, I. N. A. S., Surya, I. B. K., \& Suwandana, I. G. M. (2019). Job satisfaction moderate in self-leadership on job performance. International Research Journal of Management, IT and Social Sciences, 6(6), 270-277. https://doi.org/10.21744/irjmis.v6n6.809 